\title{
New selective earth faults only current directional method for isolated neutral systems
}

\author{
R. Granizo, F. R. Blánquez, E. Rebollo and C. A. Platero \\ Electrical Engineering Department \\ Universidad Politécnica de Madrid \\ Madrid - 28012, Spain \\ Email: ricardo.granizo@upm.es
}

\begin{abstract}
In order to achieve total selectivity at electrical distribution networks it is of great importance to analyze the defect currents at ungrounded power systems. This information will help to grant selectivity at electrical distribution networks ensuring that only the defect line or feeder is removed from service. In the present work a new selective and directional protection method for ungrounded power systems is evaluated. The new method measures only defect currents to detect earth faults and works with a directional criterion to determine the line under faulty conditions. The main contribution of this new technique is that it can detect earth faults in outgoing lines at any type of substation avoiding the possible mismatch of traditional directional earth fault relays. This detection technique is based on the comparison of the direction of a reference current to the direction of all earth fault capacitive currents at all the feeders connected to the same bus bars. This new method has been validated through computer simulations. The results for the different cases studied are remarkable, proving total validity and usefulness of the new method.
\end{abstract}

\section{NOMENCLATURE}

$I_{E i} \quad$ total defect current at principal line "i".

$I_{E i, a} \quad$ defect current at phase "a" in principal line "i".

$I_{E i j} \quad$ total defect current at secondary line "ij".

$I_{E i j, a}$ defect current at phase "a" in principal line "ij".

$I_{p i} \quad$ defect current in principal line "i" at protection relay side.

$L_{i} \quad$ principal line "i".

$L_{i j} \quad$ secondary line "ij".

$i \quad 1,2,3 \ldots n$.

j $\quad 1,2,3 \ldots \mathrm{m}$.

\section{INTRODUCTION}

Power systems are nowadays equipped with the state of the art and quite sophisticated protection devices to keep them totally safe and healthy when facing up out of range of nominal operating conditions. Such abnormal conditions like overloads, short circuits, voltage sags and drops, might represent a clear danger for the power electrical facilities as well as for their operation. Ungrounded power systems have the advantage that a single phase earth fault on the system does not produce or represent any earth fault over current to flow, and therefore, the whole system may keep its operational working conditions. In such cases, the power system must be designed to withstand high transient and steady state over voltages, so its use is generally restricted to low and medium voltage systems. Low



Fig. 1. Residual current distribution in a three line insulated system with earth fault at line L1.

and medium voltage isolated systems are normally designed to withstand during at least 8 hours, over voltages rated 1.9 p.u. of nominal value and single phase earth faults with low current values [1], [2].

\section{PROBLEMATIC OF EARTH FAULT DETECTION}

A single phase earth fault at one line of an isolated power system makes capacitive currents flow through all lines and the voltages of the healthy phases are raised up to phase-tophase voltage level [3] - [5]. Any healthy line $L_{i}$ in operation contributes to the fault with its own capacitive current $I_{E, i}$ formed by addition of its two components that correspond to the non faulty phases. For example, in Fig. 1 it is shown an earth fault in the phase "c" at line $L_{1}$. The non faulty line $L_{2}$ contributes with its capacitive current components, $I_{E 2, a}$ and $I_{E 2, b}$, flowing from the bus bars to the faulty point. Therefore, the residual current in these healthy lines correspond to their own capacitive current. On the other hand, in the faulty line the residual current is the addition of all the healthy lines capacitive currents, as the own capacitive current of the faulty line is cancelled (such current flows twice in opposite direction 
each time, see Fig. 1 where the capacitive currents for a three lines substation are shown). As it can be noted the direction of the residual current in the faulty line is opposite than the direction of the currents in the healthy lines.

These residual currents distribution makes seriously difficult to determine the right zone suffering a single phase earth fault in case of lines with different length. Under such circumstances, the actual protection devices use directional earth fault tripping criterion that measures the residual current, the residual voltage and the phase shift between them. Other research jobs about earth fault localization use modern techniques as Wavelet analysis [6] or travelling waves theory [7]. The proposed method is based on the evaluation or comparison of a reference current against the direction of the residual currents of all the lines connected to a bus. Wrong setting definition is also eliminated because of its comparison principle. This last aspect normally drives directional earth fault protections to make wrong and unintended tripping commands.

\section{PRinciples of the NeW Selective Earth FaulT DETECTION TECHNIQUE}

In case of earth fault, the capacitive currents of all the healthy lines will circulate to the faulty line. On the other hand, in the healthy lines only its own capacity current will flow. Therefore, in a power system with more than two lines of about the same length, in case of earth fault, the faulty line would have the biggest residual current among all the lines. The capacitive current $I_{C}$ of a phase in an isolated line is given by the formula:

$$
I_{C}=\frac{U_{N}}{X_{C} \cdot \sqrt{3}}
$$

where $U_{N}$ is the nominal phase-to-phase voltage of the power system. $X_{C}$ is the phase impedance value obtained from the cable data:

$$
X_{C}=\frac{1}{2 \cdot \pi \cdot f \cdot C_{\text {Cable }}}
$$

where $f$ is the frequency of the power system and $C_{C a b l e}$ is the capacitance of one phase of the cable. The more capacitance of the cable the more capacitive current it will have. Normally this capacitance is given in $\mu \mathrm{F} / \mathrm{km}$.

The proposed method is based on the comparison of the direction of the residual currents of all the lines connected to a bus, to a reference current obtained taking into account the following considerations:

- Current transformers with two identical secondary windings, named secondary one (Sec 1) and secondary two (Sec 2), are installed at all the lines [8]. In Fig.2 it is shown, in a schematic way, the current transformers used with equal and different polarity at their secondary windings. Correspondent terminals are indicated as P1 (primary terminal 1), P2 (primary terminal 2), S1 (secondary terminal 1) and S2 (secondary terminal 2).

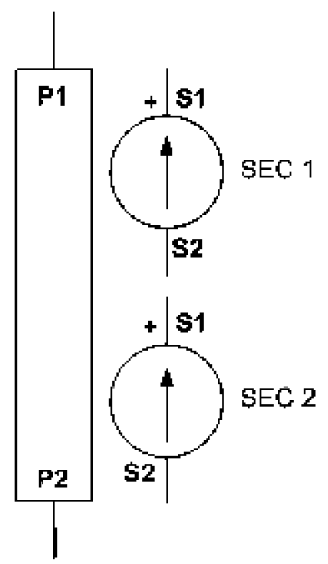

a.

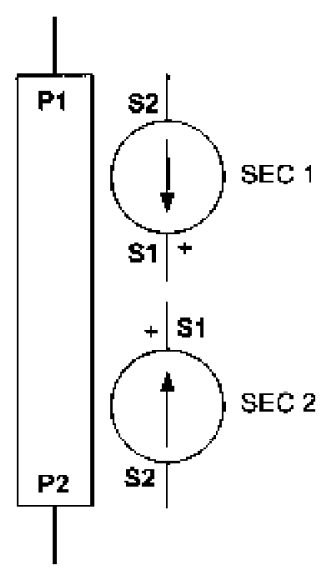

Fig. 2. Current transformer: a.) Secondary windings with equal polarity. b.) Secondary windings with different polarity.

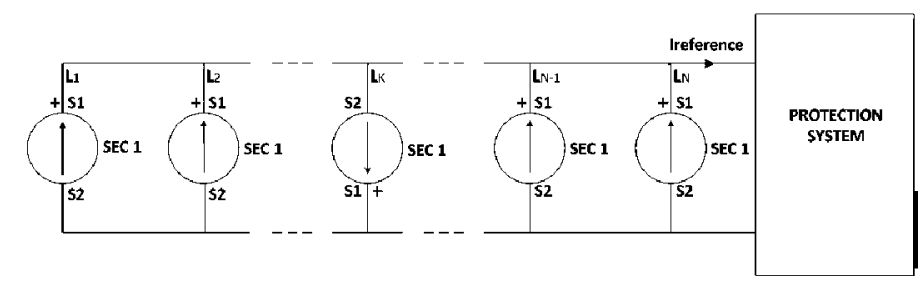

Fig. 3. Reference current circuit.

- All secondary windings one (Sec 1) have the same polarity except in one line whose secondary winding ( $\mathrm{Sec}$ 1) has reverse polarity.

- The line whose secondary winding (Sec 1) is connected with reverse polarity is chosen at random. In Fig. 3 the line $L_{k}$ is the one which secondary one (Sec 1) has been connected with reverse polarity.

- The reference current is obtained by the addition of the residual currents from all secondary one (Sec 1) windings of the current transformers installed at all the lines. In Fig. 3 it is shown the reference current obtained in a system with $\mathrm{N}$ lines connected to a bus.

- All secondary windings two (Sec 2) have been connected with the same polarity.

Therefore, the new method is able to distinguish earth faults that happen at the line whose secondary winding one ( $\operatorname{Sec} 1)$ is connected with reverse polarity, from earth faults that take place at the lines whose secondary windings one (Sec 1) have the same polarity.

The reference current is obtained adding all secondary currents of the secondary winding one (Sec 1) as indicated in Fig.3.

This new method compares the sign of the reference current to the signs of all the currents obtained from the second secondary ( $\operatorname{Sec} 2$ ). This method uses only one secondary winding one ( $\mathrm{Sec} 1$ ) with reverse polarity chosen at random. Table I shows the new selective earth fault detection technique applied to a $\mathrm{N}$-Lines power system. The current transformer 
TABLE I

FAULT EVALUATION. N-LINES SYSTEM. FAULT AT LINE $L_{K}$.

\begin{tabular}{|c|cccccc|}
\hline Line & $\mathbf{L}_{\mathbf{1}}$ & $\cdots$ & $\mathbf{L}_{\mathbf{K}}$ & $\cdots$ & $\mathbf{L}_{\mathbf{N}-\mathbf{1}}$ & $\mathbf{L}_{\mathbf{N}}$ \\
\hline $\begin{array}{c}\text { Sec. 1 } \\
\text { polarity P1 }\end{array}$ & $D$ & $\cdots$ & $I$ & $\cdots$ & $D$ & $D$ \\
\hline $\begin{array}{c}\text { Reference } \\
\text { current sign }\end{array}$ & $D$ & $\cdots$ & $D$ & $\cdots$ & $D$ & $D$ \\
\hline $\begin{array}{c}\text { Defect current } \\
\text { sign - Sec. 2 }\end{array}$ & $D$ & $\cdots$ & $I$ & $\cdots$ & $D$ & $D$ \\
\hline $\begin{array}{c}\text { Sign of } \\
\text { currents }\end{array}$ & Equal & $\ldots$ & Different & $\ldots$ & Equal & Equal \\
\hline
\end{tabular}

D:Direct — I:Inverse

TABLE II

FAULT EVALUATION. N-LINES SYSTEM. FAULT AT LINE $L_{1}$.

\begin{tabular}{|c|cccccc|}
\hline Line & $\mathbf{L}_{\mathbf{1}}$ & $\ldots$ & $\mathbf{L}_{\mathbf{K}}$ & $\ldots$ & $\mathbf{L}_{\mathbf{N}-1}$ & $\mathbf{L}_{\mathbf{N}}$ \\
\hline $\begin{array}{c}\text { Sec. 1 } \\
\text { polarity P1 }\end{array}$ & $D$ & $\ldots$ & $I$ & $\ldots$ & $D$ & $D$ \\
\hline $\begin{array}{c}\text { Reference } \\
\text { current sign }\end{array}$ & $I$ & $\ldots$ & $I$ & $\ldots$ & $I$ & $I$ \\
\hline $\begin{array}{c}\text { Defect current } \\
\text { sign - Sec. 2 }\end{array}$ & $D$ & $\ldots$ & $I$ & $\ldots$ & $D$ & $D$ \\
\hline $\begin{array}{c}\text { Sign of } \\
\text { currents }\end{array}$ & Different & $\ldots$ & Equal & $\ldots$ & Different & Different \\
\hline
\end{tabular}

D:Direct — I:Inverse

secondary one that has reverse polarity correspond to line $L_{K}$. In Table I are shown the sign of the currents measured in Sec.1 of all the lines and the sign of the reference current in case of an earth fault in line $L_{K}$.

As it can be checked, if the defect currents measured at the lines have the same polarity than the reference current at all lines except in one line, such line with different sign is the line with defect. On the other hand, in Table II is evaluated the same N-Lines power system with this new technique in case of an earth fault in line $L_{1}$. In this case, if the defect currents measured at the lines have different sign than the reference current at all the lines except in one line, such line with equal sign than the reference current is the line with defect.

\section{Simulation of the New Selective Earth Fault DETECTION TECHNIQUE}

The proposed selective earth fault protection method was simulated using ATP and MATLAB. Lines with their equivalent "pi" model for were modelled ([9], [10]) and a 132/20 $\mathrm{kV}$ power transformer with $\mathrm{YNd} 11$ connection group and 10 MVA was implemented. Two different networks have been evaluated without any load and with different types of loads such as resistive, resistive-inductive and resistive-capacitive.

\section{A. Substation with three identical lines.}

The schematic with four lines with equal length is shown in Fig. 4. Randomly, having the earth fault at the line L1, it is chosen to connect the secondary winding Sec 1 with inverse polarity in the very same line L1. Simulations show in Fig.5 the earth fault currents of all the lines connected to the $20 \mathrm{kV}$ busbars. Table III shows the signs of all earth fault currents at lines L0, L1, L2 and L3. The identification of the line $L_{1}$ as the line with an earth fault is perfectly done. Now, with the same earth fault at the line L1, it is chosen to connect the

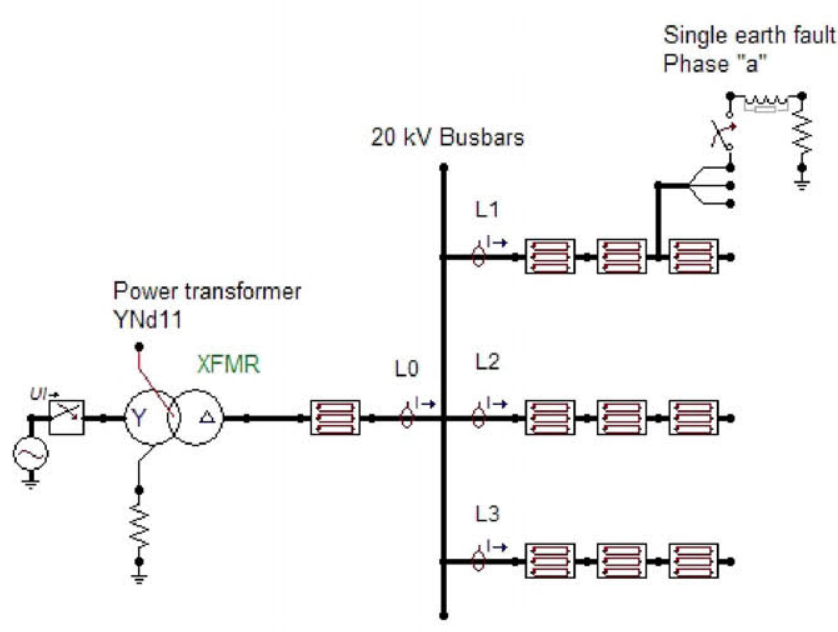

Fig. 4. ATP single line diagram for main substation arrangement.

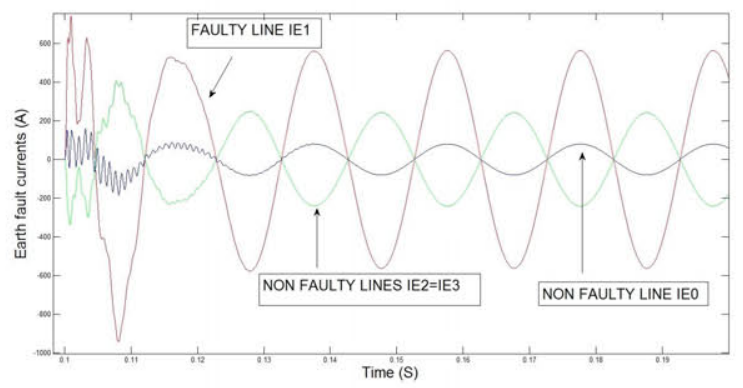

Fig. 5. Earth fault currents at $20 \mathrm{kV}$ main distribution bus bars. Single earth fault at phase "a", line $L_{1}$

TABLE III

SEC. 1 - LINE $L_{1}$ WITH REVERSE POLARITY. FAULT AT LINE $L_{1}$

\begin{tabular}{|c|cccc|}
\hline Line & $\mathbf{L}_{\mathbf{0}}$ & $\mathbf{L}_{\mathbf{1}}$ & $\mathbf{L}_{\mathbf{2}}$ & $\mathbf{L}_{\mathbf{3}}$ \\
\hline $\begin{array}{c}\text { Sec. 1 } \\
\text { polarity P1 }\end{array}$ & $\begin{array}{c}\text { Busbar } \\
\text { side }\end{array}$ & $\begin{array}{c}\text { Line } \\
\text { side }\end{array}$ & $\begin{array}{c}\text { Busbar } \\
\text { side }\end{array}$ & $\begin{array}{c}\text { Busbar } \\
\text { side }\end{array}$ \\
\hline $\begin{array}{c}\text { Reference } \\
\text { current sign }\end{array}$ & $\begin{array}{c}\text { From } \\
\text { busbars }\end{array}$ & $\begin{array}{c}\text { From } \\
\text { busbars }\end{array}$ & $\begin{array}{c}\text { From } \\
\text { busbars }\end{array}$ & $\begin{array}{c}\text { From } \\
\text { busbars }\end{array}$ \\
\hline $\begin{array}{c}\text { Defect current } \\
\text { sign - Sec. 2 }\end{array}$ & $\begin{array}{c}\text { From } \\
\text { busbars }\end{array}$ & $\begin{array}{c}\text { To } \\
\text { busbars }\end{array}$ & $\begin{array}{c}\text { From } \\
\text { busbars }\end{array}$ & $\begin{array}{c}\text { From } \\
\text { busbars }\end{array}$ \\
\hline Sign of currents & equal & different & equal & equal \\
\hline
\end{tabular}

TABLE IV

SEC. 1 - LINE $L_{2}$ WITH REVERSE POLARITY. FAULT AT LINE $L_{1}$

\begin{tabular}{|c|cccc|}
\hline Line & $\mathbf{L}_{\mathbf{0}}$ & $\mathbf{L}_{\mathbf{1}}$ & $\mathbf{L}_{\mathbf{2}}$ & $\mathbf{L}_{\mathbf{3}}$ \\
\hline $\begin{array}{c}\text { Sec. 1 } \\
\text { polarity P1 }\end{array}$ & $\begin{array}{c}\text { Busbar } \\
\text { side }\end{array}$ & $\begin{array}{c}\text { Busbar } \\
\text { side }\end{array}$ & $\begin{array}{c}\text { Line } \\
\text { side }\end{array}$ & $\begin{array}{c}\text { Busbar } \\
\text { side }\end{array}$ \\
\hline $\begin{array}{c}\text { Reference } \\
\text { current sign }\end{array}$ & $\begin{array}{c}\text { To } \\
\text { busbars }\end{array}$ & $\begin{array}{c}\text { To } \\
\text { busbars }\end{array}$ & $\begin{array}{c}\text { To } \\
\text { busbars }\end{array}$ & $\begin{array}{c}\text { To } \\
\text { busbars }\end{array}$ \\
\hline $\begin{array}{c}\text { Defect current } \\
\text { sign - Sec. } 2\end{array}$ & $\begin{array}{c}\text { From } \\
\text { busbars }\end{array}$ & $\begin{array}{c}\text { To } \\
\text { busbars }\end{array}$ & $\begin{array}{c}\text { From } \\
\text { busbars }\end{array}$ & $\begin{array}{c}\text { From } \\
\text { busbars }\end{array}$ \\
\hline Sign of currents & different & equal & different & different \\
\hline
\end{tabular}

secondary winding Sec 1 with inverse polarity in the line L3. Table IV shows the signs of all earth fault currents at all lines. Again, the identification of the line $L_{1}$ as faulty line with an earth fault is indicated. 


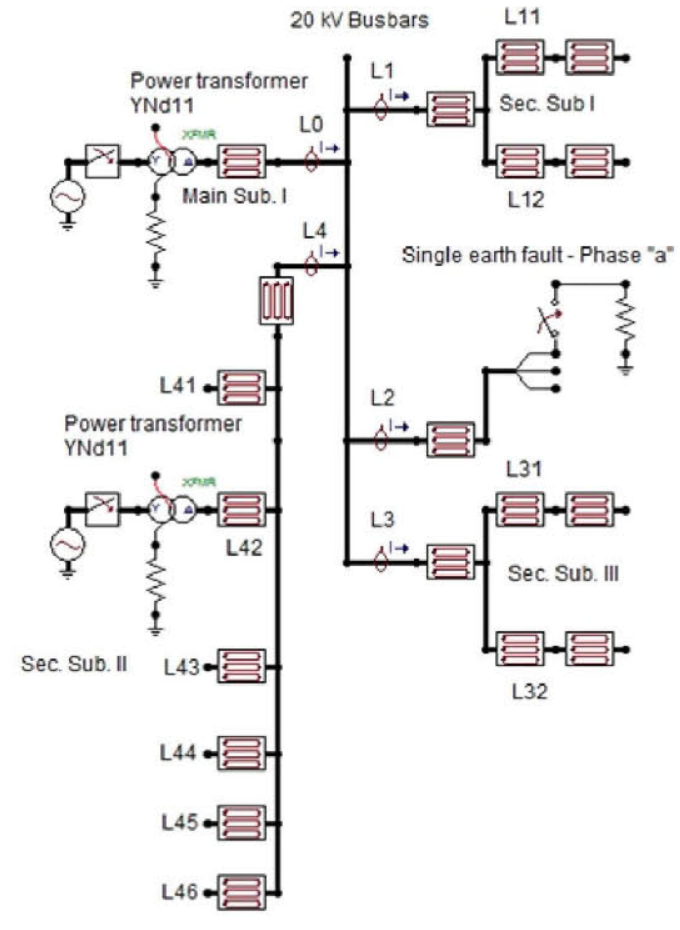

Fig. 6. Multiple substations earth fault currents at $20 \mathrm{kV}$ network. Single earth fault at phase "a", line $L_{2}$

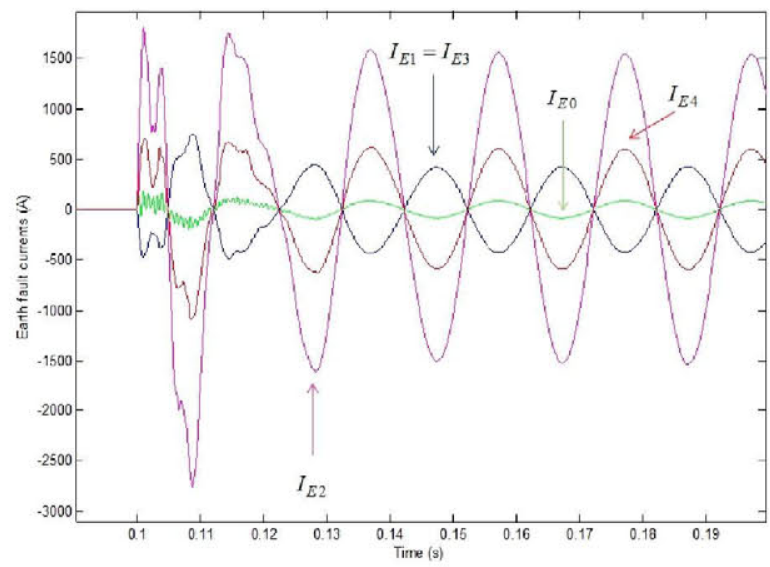

Fig. 7. Earth fault currents at $20 \mathrm{kV}$ main distribution bus bars. Single earth fault at phase "a", line $L_{2}$

\section{B. Network with multiple substations.}

The schematic with multiple lines is shown in Fig. 6. It can be seen that now there are three secondary substations beyond the main $20 \mathrm{kV}$ busbars. Randomly, having the earth fault at the line L2, it is chosen to connect the secondary winding Sec 1 with inverse polarity in the line L1. The new selective earth fault protection method is implemented at the $20 \mathrm{kV}$ bus bars.

The results show a clear identification of line $L_{2}$ as line with defect. Simulations show in Fig.7 the earth fault currents of
TABLE $\mathrm{V}$

SEC. 1 - LINE $L_{1}$ WITH REVERSE POLARITY. FAULT AT LINE $L_{2}$.

\begin{tabular}{|c|ccccc|}
\hline Line & $\mathbf{L}_{0}$ & $\mathbf{L}_{1}$ & $\mathbf{L}_{2}$ & $\mathbf{L}_{3}$ & $\mathbf{L}_{4}$ \\
\hline $\begin{array}{c}\text { Sec. 1 } \\
\text { polarity P1 }\end{array}$ & $\begin{array}{c}\text { Busbar } \\
\text { side }\end{array}$ & $\begin{array}{c}\text { Line } \\
\text { side }\end{array}$ & $\begin{array}{c}\text { Busbar } \\
\text { side }\end{array}$ & $\begin{array}{c}\text { Busbar } \\
\text { side }\end{array}$ & $\begin{array}{c}\text { Busbar } \\
\text { side }\end{array}$ \\
\hline $\begin{array}{c}\text { Reference } \\
\text { current sign }\end{array}$ & $\begin{array}{c}\text { To } \\
\text { busbars }\end{array}$ & $\begin{array}{c}\text { To } \\
\text { busbars }\end{array}$ & $\begin{array}{c}\text { To } \\
\text { busbars }\end{array}$ & $\begin{array}{c}\text { To } \\
\text { busbars }\end{array}$ & $\begin{array}{c}\text { To } \\
\text { busbars }\end{array}$ \\
\hline $\begin{array}{c}\text { Defect current } \\
\text { sign - Sec. 2 }\end{array}$ & $\begin{array}{c}\text { From } \\
\text { busbars }\end{array}$ & $\begin{array}{c}\text { From } \\
\text { busbars }\end{array}$ & $\begin{array}{c}\text { To } \\
\text { busbars }\end{array}$ & $\begin{array}{c}\text { From } \\
\text { busbars }\end{array}$ & $\begin{array}{c}\text { From } \\
\text { busbars }\end{array}$ \\
\hline Sign of currents & different & different & equal & different & different \\
\hline \hline
\end{tabular}

TABLE VI

SEC.1 - LINE $L_{2}$ WITH REVERSE POLARITY. FAULT AT LINE $L_{2}$.

\begin{tabular}{|c|ccccc|}
\hline Line & $\mathbf{L}_{0}$ & $\mathbf{L}_{1}$ & $\mathbf{L}_{2}$ & $\mathbf{L}_{3}$ & $\mathbf{L}_{4}$ \\
\hline $\begin{array}{c}\text { Sec. 1 } \\
\text { polarity P1 }\end{array}$ & $\begin{array}{c}\text { Busbar } \\
\text { side }\end{array}$ & $\begin{array}{c}\text { Busbar } \\
\text { side }\end{array}$ & $\begin{array}{c}\text { Line } \\
\text { side }\end{array}$ & $\begin{array}{c}\text { Busbar } \\
\text { side }\end{array}$ & $\begin{array}{c}\text { Busbar } \\
\text { side }\end{array}$ \\
\hline $\begin{array}{c}\text { Reference } \\
\text { current sign }\end{array}$ & $\begin{array}{c}\text { From } \\
\text { busbars }\end{array}$ & $\begin{array}{c}\text { From } \\
\text { busbars }\end{array}$ & $\begin{array}{c}\text { From } \\
\text { busbars }\end{array}$ & $\begin{array}{c}\text { From } \\
\text { busbars }\end{array}$ & $\begin{array}{c}\text { From } \\
\text { busbars }\end{array}$ \\
\hline $\begin{array}{c}\text { Defect current } \\
\text { sign - Sec. 2 }\end{array}$ & $\begin{array}{c}\text { From } \\
\text { busbars }\end{array}$ & $\begin{array}{c}\text { From } \\
\text { busbars }\end{array}$ & $\begin{array}{c}\text { To } \\
\text { busbars }\end{array}$ & $\begin{array}{c}\text { From } \\
\text { busbars }\end{array}$ & $\begin{array}{c}\text { From } \\
\text { busbars }\end{array}$ \\
\hline Sign of currents & equal & equal & different & equal & equal \\
\hline \hline
\end{tabular}

all the lines connected to the $20 \mathrm{kV}$ busbars. Table $\mathrm{V}$ shows the signs of all earth fault currents at lines L0, L1, L2 and L3. Finally, with the same earth fault at the line L2, it is chosen to connect the secondary winding Sec 1 with inverse polarity in the same line L2. The result also shows that line $L_{2}$ has an earth fault defect. Table VI shows the signs of earth fault currents at lines L0, L1, L2, L3 and L4 in this last configuration.

\section{CONCLUSIONS}

A new selective earth fault technique for isolated networks has been presented in this job. This new method is suitable for all kind of substations. Current transformers with two identical secondary windings are installed at all the lines. The proposed directional detection technique is based on the comparison of the direction of the defect currents of all lines connected to the same busbars to a reference current. This reference current is obtained by the addition of all residual currents obtained from all current transformers installed at all lines with the particularity of having only one current transformer connected in reverse polarity compared to the rest ones. Therefore, the new method distinguishes earth faults that happen at any line without measuring any residual voltage or phase voltage. No traditional directional tripping obtained from the comparison of the residual voltage and earth fault current is used. The aforementioned advantages grant a great improvement in the network protection system as non intended trips caused by single earth faults are eliminated.

\section{REFERENCES}

[1] Donald Reimert, "Protective Relaying for Power Generation Systems". CRC Press, Taylor \& Francis Group. 2006, ISBN-13: 978-0-8247-07002, pp. $146-151$.

[2] J.Duncan Glover, Mulukkutla S.Sarma, "Power System Analysis and Design", Third Edition, Brooks/ Cole, 2002. ISBN 0-534-95367-0, Chapter 9 "Unsymmetrical Faults".

[3] M.M. Saha, J.Izykowsky, E. Rosolowsky, "Fault Location on Power Networks", Ed. Springer. 2009, ISBN 978-1-84882-886-5. 
[4] Zhang Qinchao, Zhang Yao, Song Wennan, Yu Yixin, "Fault location of two parallel transmission line for non earth fault using one terminal data", IEEE Transactions on Power Delivery. Vol.14, No.3, July 1999.

[5] Sachdev, M.S, and Agarwal, R.: "A technique for estimating transmission line fault locations from digital impedance relay measurements", IEEE Transactions on Power Delivery, 121-129, 3, (1), pp.1988.

[6] Jun Liang, Zengxun Liu, Zhihao Yun, Mei Li, Li Zhang, "A New Method for Earth Fault Line Detection Based on Two-Dimensional Wavelet Transform in Distribution Automation", 2005 IEEE/PES Transmission and Distribution Conference \& Exhibition: Asia and Pacific, Dalian, China

[7] Zengwei Guo, feng Yan, "Fault Location for $10 \mathrm{kV}$ Distribution Line Based on Travelling Wave - DC Theory", Power and Energy Engineering Conference (APPEEC), 2010 Asia-Pacific, 10.1109/APPEEC.2010.5448924.

[8] EN 60044-1, Instrument Transformers. Part 1. European Standard. October 2001 .

[9] Al-Saud M.S., El-Kady M.A., Findlay R.D., A new approach to underground cable performance assessment. Electric Power Systems Research 78 (2008) 907-918.

[10] "Reglamento sobre condiciones técnicas y garantías de seguridad en las líneas eléctricas de alta tensión". ITC-LAT-07. Ministerio de Industria, España. Madrid 2009. 